\title{
Protective Effect of Omega 3 and Vitamin $D$ in Preventing Lung-tissue Damage of Newborn Rats Exposed to Cigarette Smoke during Intrauterine Period
}

\author{
Efecto Protector de Omega 3 y Vitamina D en la Prevención del Daño en el Tejido Pulmonar \\ de Ratas Recién Nacidas Expuestas al Humo del Cigarrillo durante el Período Intrauterino
}

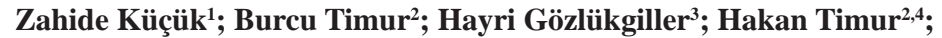 \\ Kudret Erkeneklii ${ }^{4}$ Muzaffer Çaydere ${ }^{5}$ \& Aytekin Tokmak $^{4}$
}

\begin{abstract}
KÜÇÜK, Z.; TIMUR, B.; GÖZLÜKGILLER, H.; TIMUR, H.; ERKENEKLI, K.; ÇAYDERE, M. \& TOKMAK, A. Protective effect of Omega 3 and vitamin D in preventing lung-tissue damage of newborn rats exposed to cigarette smoke during intrauterine period. Int. J. Morphol., 37(1):87-92, 2019.
\end{abstract}

SUMMARY: This study aimed to investigate the toxic effects of cigarette smoke exposure on lung and the protective role of Omega 3 and Vitamin D against these toxic effects biochemically and histologically. 28 pregnant Wistar Albino rats were divided into four groups. The first group was control group; the second group was exposed to smoke of 10 cigarette by puff device 2 hours/day after pregnancy; the third group was exposed to cigarette smoke together with Omega $3(0.5 \mathrm{mg} / \mathrm{kg} / \mathrm{day})$ and the fourth group was exposed to cigarette smoke together with vitamin D (42 microgram/kg/day). Finally, lung tissue sections of the newborn rats were stained with Hemotoxilen eosine and Masson tricromite. Malondialdehyde (MDA) and Fluorescent Oxidation Products (FOU) levels were measured. Fetal weights and the number of fetuses were significantly lower in the group received only cigarette smoke (both $\mathrm{p}<0.001)$. Histopathologically, pulmonary volume, number of developed alveols and parenchyma elasticity decreased significantly, meanwhile interstitial tissue increased, elastin and collagen did not develop adequately. Histopathologic changes significantly decreased in the group given Omega 3 and Vitamin D. Statistically, MDA and FOU levels were found to be higher in the group exposed to cigarette smoke compared to the control group, and MDA and FOU levels were lower in the group given Omega 3 along with cigarette smoke ( $<<0.001)$. Cigarette smoke caused histologically significant damage to fetal lung tissue, oxidative stress and increased MDA and FOU levels. This damage was significantly reduced with Omega 3 and Vitamine D supplementation. Omega 3 is an important antioxidant; vitamin D has no significant antioxidant effect.

KEY WORDS: Maternal cigarette smoke; Fetal lung; MDA and FOU; Omega 3, Vitamin D.

\section{INTRODUCTION}

Maternal cigarette smoking is an extremely important issue in terms of mother and baby health, as well as the growth of healthy generations. Since smoking is an important risk factor in morbidity and mortality, a large number of studies on this topic have been made and continue to be made. In proportion to the increase of daily smoking amount during pregnancy period; complications such as miscarriages, gestational hypertension, preeclampsia, placenta previa, placenta ablation, premature rupture of membranes, premature birth, stillbirth, intrauterin generation restriction may occur (Ananth et al., 1996; Wollmann, 1998).
Cigarette smoking during pregnancy has been shown to reduce lung function in children and to increase the risk of developing serious infections such as respiratory syncytial virus bronchiolitis, meningococcal diseases, lower respiratory tract infections, middle ear infections (SchulteHobein et al., 1992). Additionally, Jaakkola \& Gissler (2004) have shown that exposure to intrauterine cigarette smoke also increases the risk of asthma in childhood. Meanwhile, studies have been carried out to determine that it causes behavioral and psychiatric side effects, attention deficit hyperactivity disorder (ADHD), mental retardation,

\footnotetext{
${ }^{1}$ Yuksek Ihtisas University, Koru Ankara Hospital, Department of Obstetrics and Gynaecology, Ankara, Turkey.

${ }^{2}$ Ordu University Education and Research Hospital, Department of Obsterics and Gynaecology, Ordu, Turkey.

${ }^{3}$ Altinbas University, Medical Park Bahcelievler Hospital, Department of Pediatrics, Istanbul, Turkey.

${ }^{4}$ Zekai Tahir Burak Women's Health Education and Research Hospital, Department of Obstetrics and Gynecology, Ankara, Turkey.

${ }^{5}$ Ankara Education and Research Hospital, Department of Pathology, Ankara, Turkey.
} 
childhood cancers among children (Hofhuis et al., 2002; Batstra et al., 2003).

Omega- 3 is one of the important fatty acids that cannot be produced in the body but only taken with food to participate in the structure of the cell membrane. It is mainly found in vegetable oils such as flax seeds, walnuts, soybean oil, and plenty of green leafy vegetables. It has long been known that omega- 3 fatty acids have positive effects on the mental and physical development of the baby during the intrauterine period. Today it takes place in treatment guidelines for many diseases, primarily in cardiovascular diseases, to help prevent insulin resistance and controlling weight in obese children, to help with ADHD, and to strengthen the immune system (Young \& Conquer, 2002; Balk et al., 2006)

Vitamin D is also an important steroid hormone that has different cellular receptors in many different tissues such as lung tissue, other than its role in calcium hemostasis in bone metabolism, which is already known for a long time. Numerous studies have been carried out on vitamin D deficiency in pregnancy and found to be associated with an increase in risky conditions such as gestational diabetes, preeclampsia and infants with low birth weight (Urrutia \& Thorp, 2012). Recent studies have shown that with its antiinflammatory and antimicrobial properties vitamin D prevents systemic inflammation. During pregnancy, Vitamin $\mathrm{D}$ has been found to have an important effect on the growth and development of fetal lung tissue, resulting in a decrease in respiratory tract infections as a result of strengthening the immunity system (Camargo et al., 2007; Litonjua, 2012).

Despite many studies on omega 3 and vitamin D, studies on how these vitamins affect the fetal lung exposed to cigarette smoke are inadequate. More studies are required to find out certain effects. In our study by using biochemical and light microscopic parameters, the toxic effects of cigarette smoke exposure on the lungs and the protective role of omega 3 and vitamin D against these toxic effects were investigated.

\section{MATERIAL AND METHOD}

Twenty eight adult female Wistar Albino rats were used in the study. The weights of the rats ranged from 150 to200 gr. During the experiment, the rats were housed in wire-mesh cages with a diameter of $30 * 60 * 30 \mathrm{~cm}$, each of which had 7 pregnant rats. The rats were fed with enough (ad libitium) feed (Feed Institute Standard Pellet Rat Feed) and tap water in a 12-hour day, 12-hour night setting. It was kept at normal room temperature $\left(22 \pm 1^{\circ} \mathrm{C}\right)$ and humidity. All rats were pregnant and pregnancies were determined by the formation of a solid, yellow vaginal plaque. The appearance of vaginal plaque was accepted as the first day of the pregnancy.

The rats in the first group (Group I, control group) were provided to be pregnant following the mating of the rats. The mother rats were observed spontaneously without any special treatment. Following the birth, newborn rats were held in the same cage as their mothers, and only breastfed. Following the pregnancy, the rats in the second group (Group II) were exposed cigarette smoke of 10 pieces with the puff device for 2 hours / day. The pregnant rats in the third group (Group III) were given 2 hours / day cigarette smoke + Omega $3(0.5 \mathrm{mg} / \mathrm{kg}$ / day $)$ following the pregnancy. The fourth group (Group IV) of pregnant rats was exposed to cigarette smoke together with vitamin D (42 microgram / kg / day). The newborn rats were kept in the same environment with the mothers for 10 days, allowing them to only breastfeed and be exposed to cigarette smoke. Vitamin D and Omega 3 were given intraperitoneally.

Baby rats were weighed and macroscopically examined to determine if there was any abnormality or pathology. On the 10th day after birth, lung tissues were taken with appropriate incision following anesthetizing newborn rats with ketamine and sent to the pathology and biochemistry departments. These lung tissues were histologically investigated routinely and paraffin-blocked. 5-6 $\mathrm{mm}$ sections prepared from paraffin blocks, were stained with Hematoxylin-Eosine and with Masson tricrom to better demonstrate fibrosis. With systematic random sampling, 7 lung preparations belonging to each group were selected. Then, according to the scoring method published in the literature, each of the preparations was grouped according to the degree of change level between 0-6 (0No change, 1- Minimum level, 2- Low level, 3- Medium level, 4- Severity level 5- Intense level, 6- Very intense level) (Sahin et al., 2006).

Biochemical parameters Malondialdehyde (MDA) and Fluorescent Oxidation Products (FOU) levels were measured in lung tissue, to determine if there were differences between the groups in terms of oxidation products. MDA levels were measured using the fluorometric method as described by Wasowicz et al. (1993) Fluorescent oxidation products were measured with modified Shimasaki (1994) methods. Briefly tissue homogenates were extracted with ethanol-ether $(3 / 1 \mathrm{v} / \mathrm{v})$ and were measured by spectroflurometrically at a wavelengght of 360/430 (exitation/emmision wavelenght). 
Statistical Analysis. The Shapiro-Wilk test was used to determine whether or not continuous variables were normally distributed. Levene test was used for the evaluation of homogeneity of variances. Data were expressed as mean $\pm \mathrm{SD}$ or median (interquartile range), where applicable. While the mean differences among groups were analyzed by One-Way ANOVA, the Kruskal Wallis test was applied for the comparisons of not normally distributed data. When the $\mathrm{p}$ value from One-Way ANOVA or Kruskal Wallis test statistics were statistically significant post-hoc Tukey HSD or Conover's multiple comparison test were used to determine which group differ from which others. Data analysis was performed by using IBM SPSS Statistics version 17.0 software (IBM Corporation, Armonk, NY, USA). A p value less than 0.05 was considered as statistically significant.

\section{RESULTS}

There was a statistically significant difference between groups in terms of mean body weights $(p<0.001)$. Group II and III had lower body weight than Group I had $(12.9 \pm 0.9$ vs $18.4 \pm 1.4 \mathrm{~g}, \mathrm{p}<0.001$ and $16.0 \pm 0.8$ vs 18.4 $\pm 1.4 \mathrm{~g}, \mathrm{p}<0.001$, respectively). In addition, Group III and IV had higher body weight than Group II ( $16.0 \pm 0.8$ vs 12.9 $\pm 0.9 \mathrm{~g}, \mathrm{p}<0.001$ and $17.4 \pm 1.0$ vs $12.9 \pm 0.9 \mathrm{~g}, \mathrm{p}<0.001$ ). Body weights were similar between Group I and IV and between Group III and IV ( $p=0.304$ and $p=0.077)$. There was a statistically significant difference between groups in terms of median fetus numbers ( $\mathrm{p}<0.001)$. Group II and III had lower fetal numbers than Group I ( $p<0.001$ and $p$ $<0.001$ ). In addition, the number of fetuses in Group III and IV was higher than in Group II and the number of fetuses in Group IV was higher compared to Group III ( $p=0.003$, p $<0.001$ and $p<0.001$ ). There was no statistically significant difference between groups I and IV in terms of fetal numbers $(p=0.843)$ (Fig. 1). There was a statistically significant difference between groups in terms of histological change scores ( $p<0.001)$. Group II, III and IV showed more changes than Group I ( $p<0.001)$. Furthermore, there was less variation in Group III and IV when compared to Group II (p $<0.001$ ). There was no significant difference between groups III and IV ( $\mathrm{p}=0.194)$ (Table I).

There was a statistically significant difference $(p=0.036)$ between the groups in terms of MDA measurements made in the lung samples, and the difference in the MDA levels of Group III in contrast to Group II was found to be lower $(p=0.037)$. There was no statistically significant difference between MDA levels of the other groups $(p>0.05)$. There was a statistically significant difference $(p=0.001)$ between the groups in terms of mean FOU levels measured from the lungs. Group III and IV had lower FOU levels than in Group I ( $p<0.001$ and $p=0.017$ ). In addition, compared to Group II, the FOU level was also lower in Group III $(\mathrm{p}=0.025)$. (Table II)
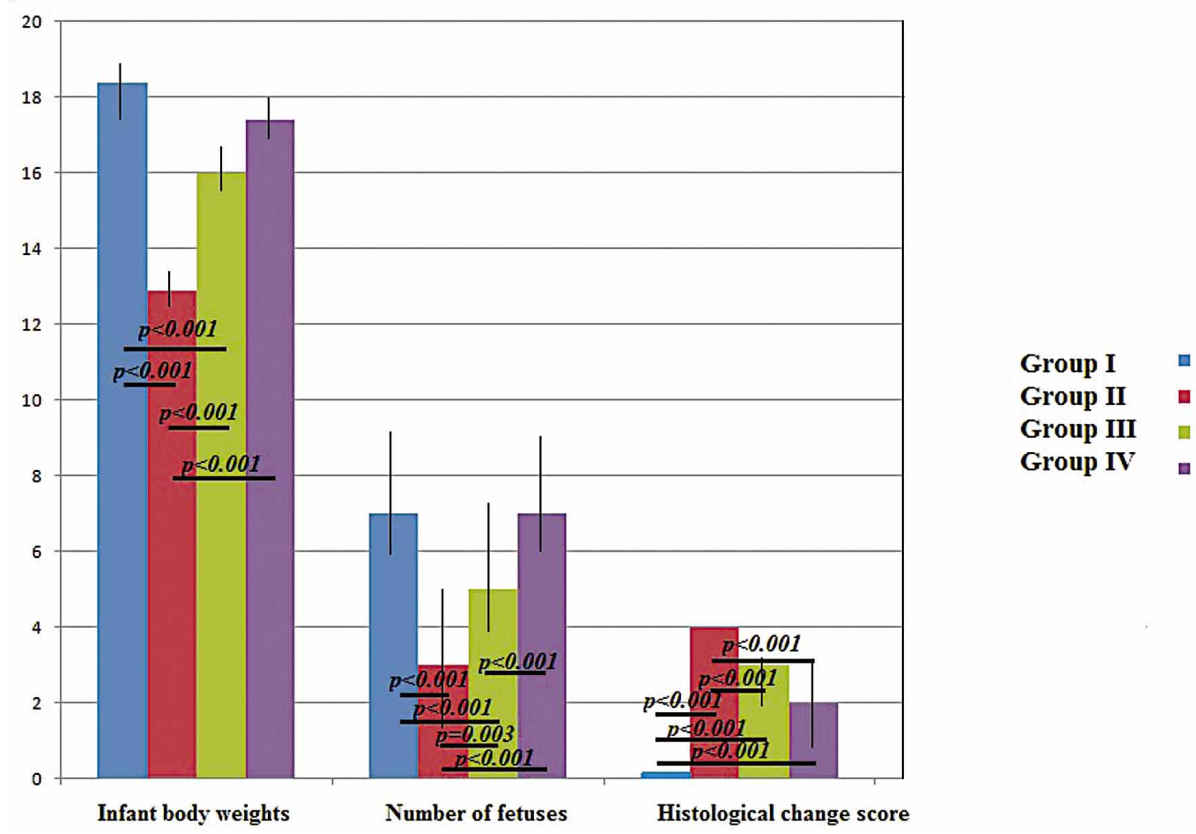

Fig. 1. Differences in intragroup birth weights, fetus numbers and histological change scores between the groups. 
KÜÇÜK, Z.; TIMUR, B.; GÖZLÜKGILLER, H.; TIMUR, H.; ERKENEKLI, K.; ÇAYDERE, M. \& TOKMAK, A. Protective effect of Omega 3 and vitamin D in preventing lung-tissue damage of newborn rats exposed to cigarette smoke during intrauterine period. Int. J. Morphol., 37(1):87-92, 2019.

Table I. Comparison of birth weights, fetus numbers and histological change scores among treatment groups.

\begin{tabular}{lccccc}
\hline Variables & Group I & Group II & Group III & Group IV & $p$-value \\
\hline Mean body weight $(\mathrm{g})$ & $18.4 \pm 1.4$ & $12.9 \pm 0.9$ & $16.0 \pm 0.8$ & $17.4 \pm 1.0$ & $<0.001 \dagger$ \\
Fetus number & $7(6-9)$ & $3(0-5)$ & $5(4-7)$ & $7(6-9)$ & $<0.001$ ฯ \\
Change score & 0 & 4 & $3(2-3)$ & $2(1-3)$ & $<0.001$ ฯ \\
\hline
\end{tabular}

$\dagger$ One-way ANOVA test. $\uparrow$ Kruskal Wallis test.
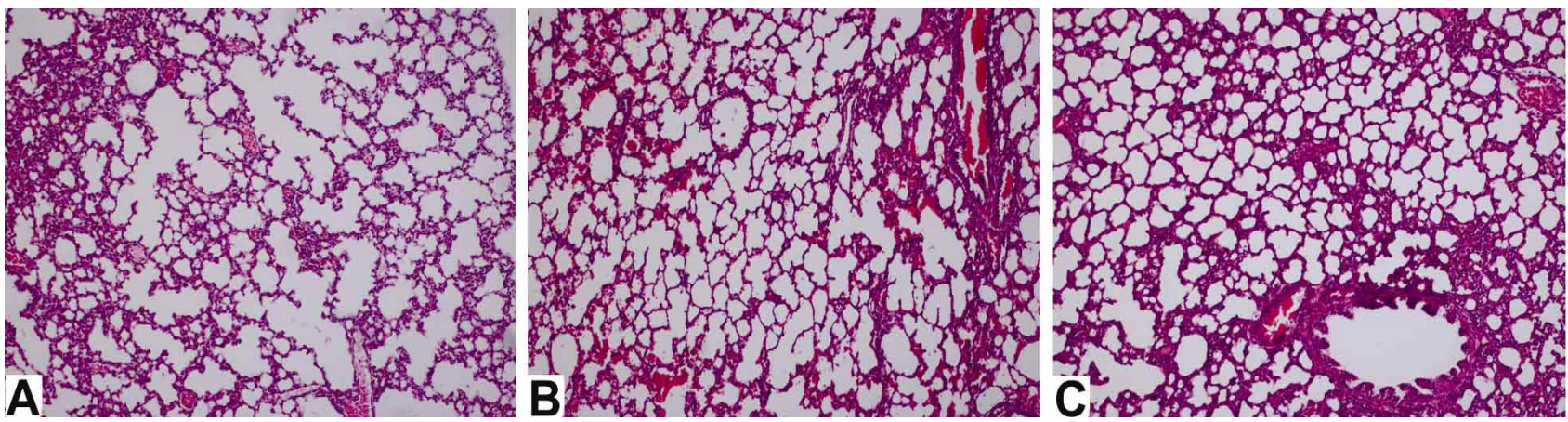

Fig. 2. a) Advanced degree septal thickness, fibrosis, and alveolar fragmantation are seen in group II. Connective tissue increment is also striking. b) Focal fibrosis areas and emphysematous changes are remarkable in Group III. c) Septal thickening, fibrosis, and connective tissue increment are significantly decreased in Group IV. Emphysematous changes in alveoli are also relatively decreased in this group.

Table II. Comparison of serum MDA and FOU (ng/mL) levels among treatment groups.

\begin{tabular}{cccccc}
\hline Variables & Group I & Group II & Group III & Group IV & $p$-value \\
\hline MDA $(\mathrm{ng} / \mathrm{mL})$ & $1535.9 \pm 434.8$ & $1953.1 \pm 907.3^{\mathrm{A}}$ & $818.4 \pm 200.1^{\mathrm{A}}$ & $1820.0 \pm 1045.0$ & $0.036 \dagger$ \\
FOU $(\mathrm{ng} / \mathrm{mL})$ & $336.9 \pm 101 . \mathrm{B}^{\mathrm{C}}{ }^{\mathrm{C}}$ & $277.1 \pm 82.2^{\mathrm{D}}$ & $145.4 \pm 52.2^{\mathrm{B}, \mathrm{D}}$ & $197.4 \pm 77.9 \mathrm{C}$ & $0.001 \dagger$
\end{tabular}

MDA; Malondialdehyde, FOU; Fluorescent Oxidation Products, $\dagger$ One-way ANOVA test. ${ }^{\mathrm{A}}$ MDA levels; Group II vs Group III; $\mathrm{p}=0.037$, ${ }^{\mathrm{B}} \mathrm{FOU}$ levels; Group I vs Group III; $\mathrm{p}=0.001$, ${ }^{\mathrm{C}} \mathrm{FOU}$ levels; Group I vs Group IV; $\mathrm{p}=0.017$, ${ }^{\mathrm{P} F O U}$ levels; Group II vs Group III; $\mathrm{p}=0.025$.

The fetuses were evaluated in terms of head, truncus and limbs anomalies, and no significant difference between the groups was found $(\mathrm{p}>0.05)$. Histopathological examination of the lung tissue showed that the fetuses in the second group exposed to cigarette smoke have decreased lung volumes, reduced alveol numbers, increased interstitial thickness and thinned alveolar septations. We also found that distal alveoli merged and formed large air gaps, and Masson tricrom-stained sections had significant fibrosis increase. We determined that these histopathologic changes were significantly reduced in the groups given Omega 3 and Vitamin D, that the pulmonary volume and the number of developed alveoli were similar to the control group, that emphysematous vacuoles, fibrosis has been regressed $(p<0.001)$. Comparisons of these changes in lung tissue between groups are shown in Figure 2.

\section{DISCUSSION}

In our study, the possible harmful effects of cigarette smoke exposure on fetal morphological structures and lung development in pregnant rats; the possible protective role of Omega 3 and vitamin D against these harmful effects were investigated with measurements, histological examinations and biochemical analyzes.

In previous studies, cigarette smoke was found to cause low birth weight, increase in premature births and spontan abortus (Lambert \& Clark, 1996). In another study by Zavos (1989), it was determined that cigarette had negative effects on tubal function, oocyte development and embryo formation. In relation to these side effects, Pattinson 
KÜÇÜK, Z.; TIMUR, B.; GÖZLÜKGILLER, H.; TIMUR, H.; ERKENEKLI, K.; ÇAYDERE, M. \& TOKMAK, A. Protective effect of Omega 3 and vitamin D in preventing lung-tissue damage of newborn rats exposed to cigarette smoke during intrauterine period. Int. J. Morphol., 37(1):87-92, 2019.

et al. (1991) showed that it caused a reduction in births and fetal weights. In our study, fetal weights were significantly lower in the group exposed only to cigarette smoke than in the control group. The number of fetuses in the group exposed to cigarette smoke was also significantly lower in terms of fetus numbers among the groups. In the groups given omega 3 and Vitamin D together with cigarette smoke, fetal weight and number of fetuses were significantly higher when compared with the group exposed only to cigarette smoke.

Although smoking is harmful to all individuals, the harmful effects on fetuses and infants are much greater. In particular, cigarette smoke affects the development and function of the lungs of the fetus severely (Karlıkaya et al., 2006). It has been determined that when exposed to cigarette smoke, the lung volumes of the fetuses and the number of advanced alveoli decreased, interstitial tissue thickened, elastin and collagen production decreased. It has been detected that infants of maternal smokers have coughs, wheezing, respiratory hypersensitivity, decreased respiratory function, and these effects are more pronounced in boys (Gürkan et al., 2000; Avol et al., 2001). Similar to the these studies, in our study, we observed that the lung volume and the alveol numbers decreased, the interstitial tissue and fibrosis increased, there were thinned alveolar septas and the alveoli merged to form large air gaps in the fetuses in the group exposed only to cigarette smoke.

It has been known for many years that Omega 3 fatty acids have antiinflammatory and antioxidant properties. In the studies, it has been reported that omega-3 can be used in the treatment of cardiovascular diseases, hypertension, allergic asthma, autoimmune diseases (Oosthuizen et al., 1994; Mckeever et al., 2008). Mckeever et al. reported that Omega 3 protects respiratory tissues against oxidative stress, improves lung function, and alleviates chronic obstructive pulmonary disease (COPD) and asthma symptoms. In particular, it was emphasized that Omega 3 medication has protective effect against respiratory hypersensitivity. Accordingly, Omega 3 has begun to take place in the treatment protocol for respiratory diseases such as asthma and COPD (Romieu \& Trenga, 2001; Slinde et al., 2005). Similar to these studies, we also found that damage to the lung tissue caused by cigarette smoke could be significantly prevented by Omega 3, that alveol numbers increased, the volume of the lung tissue was similar to the control group, and fibrosis regressed.

Vitamin D used during pregnancy has been shown to induce maturation of type 2 alveolar cells, which has an important effect in fetal lung development, pulmonar surfactant synthesis and to have an important effect in fetal lung development (Foong et al., 2014). Berraies et al. (2014) pointed out that Vitamin D deficiency resulted in decreased lung volume, decreased lung parenchyma and thinned alveolar septa in female rats. In a different study vitamin D has been shown to be protective against asthma and wheezing, to reduce respiratory tract infections by improving immunological function and showing an anti-inflammatory effect (Litonjua). It has been determined that low maternal Vitamin D intake in pregnancy increases the risk of wheezing in three year-old-children (Camargo et al,). In our study, in the group that we gave vitamin D together with cigarette smoke, we also found that the lung volume and the alveol numbers significantly increased, that there was a regression in the emphysematous gaps, that the intertial tissue and the alveolar septa was similar to the control group, and that fibrosis regressed. We found that Vitamin D significantly reduced the damage on lung tissue caused by cigarette smoke.

One of the negative effects of cigarette smoking is the oxidative stress that it forms in the lung tissue. Oxidative stress is a cell-damaging process caused by free radicals. MDA, a lipid peroxidation product, is one of the important parameters used to show oxidative damage to the tissue. In our study, we found that tissue MDA levels were significantly higher in the group exposed to cigarette smoke $(p<0.05)$. We have seen that Omega 3 significantly reduced the level of MDA by its strong antioxidant effect; Vitamin $\mathrm{D}$, however, did not have a significant effect on MDA levels. Levels of fluorescent oxidation products were significantly, positively associated with variables linked with systemic oxidative stress, including smoking, hypertension, and reduced renal function. This marker increased significantly with number of cigarettes smoked per day. We found that the fetus exposed to cigarette smoke had a high FOU level in the pulmonary tissue and this level decreased significantly with the intake of Omega 3. Vitamin D, however, did not have a significant effect on FOU level. Based on this information, we have shown that Omega 3 significantly reduces the levels of MDA and FOU that the cigarette produces as a result of oxidative stress, and that it positively affects tissue damage.

As a result we found that cigarette smoke caused significant damage to the fetal lung tissue histologically, increased tissue MDA and FOU levels by leading to oxidative stress. We found that this damage was significantly reduced with Omega 3 and Vitamin D supplementation, that Omega 3 fatty acid is an important antioxidant and while Vitamin D has no significant antioxidant effect. We believe that Omega 3 and Vitamine D intake is very important for both mother and fetus health during pregnancy for their functional and metabolic tasks, and so that all pregnant women, especially maternal smokers, should be given Omega 3 and Vitamine D supplementation. 
KÜÇÜK, Z.; TIMUR, B.; GÖZLÜKGILLER, H.; TIMUR, H.; ERKENEKLI, K.; ÇAYDERE, M. \& TOKMAK, A. Efecto protector de Omega 3 y vitamina $\mathrm{D}$ en la prevención del daño en el tejido pulmonar de ratas recién nacidas expuestas al humo del cigarrillo durante el período intrauterino. Int. J. Morphol., 36(4):87-92, 2018.

RESUMEN: Este estudio tuvo como objetivo investigar los efectos tóxicos de la exposición al humo de cigarrillo en el pulmón, y el papel protector de Omega 3 y la Vitamina D contra esos efectos. 28 ratas Wistar albino preñadas fueron separadas en cuatro grupos. El primer grupo grupo control; el segundo grupo estuvo expuesto al humo de 10 cigarrillos por dispositivo de inhalación 2 horas / día después de la preñez; el tercer grupo se expuso al humo del cigarrillo junto con Omega 3 (0,5 mg / kg / día) y el cuarto grupo se expuso al humo del cigarrillo junto con vitamina D (42 microgramos / kg / día). Secciones de tejido pulmonar de las ratas recién nacidas se tiñeron con Hematoxilina Eosina y tricrómico de Masson. Se midieron los niveles de malondialdehído (MDA) y productos de oxidación fluorescente (POF). Los pesos fetales y el número de fetos fueron significativamente más bajos en el grupo que recibió solamente humo de cigarrillo (ambos p <0,001). Histopatológicamente, el volumen pulmonar, el número de alveolos desarrollados y la elasticidad del parénquima disminuyeron significativamente; mientras que el tejido intersticial aumentó y la elastina y el colágeno no se desarrollaron adecuadamente. Los cambios histopatológicos disminuyeron significativamente en el grupo que recibió Omega 3 y Vitamina D. Estadísticamente, se encontró que los niveles de MDA y POF eran más altos en el grupo expuesto al humo de cigarrillo en comparación con el grupo control, además los niveles de MDA y POF fueron más bajos en el grupo que recibió Omega 3 junto con el humo del cigarrillo ( $\mathrm{p}<0,001)$. El humo del cigarrillo causó daños histológicamente significativos en el tejido pulmonar fetal, el estrés oxidativo y el aumento de los niveles de MDA y FOU. Este daño se redujo significativamente con los suplementos de Omega 3 y Vitamina D. El omega 3 es un importante antioxidante; la vitamina D no tiene ningún efecto antioxidante significativo.

PALABRAS CLAVE: Humo materno del cigarrillo; Pulmón fetal; Malondialdehído; Productos de oxidación fluorescente; Omega 3, Vitamina $D$.

\section{REFERENCES}

Ananth, C. V.; Savitz, D. A. \& Luther, E. R. Maternal cigarette smoking as a risk factor for placental abruption, placenta previa, and uterine bleeding in pregnancy. Am. J. Epidemiol., 144(9):881-9, 1996.

Avol, E. L.; Gauderman, W. J.; Tan, S. M.; London, S. J. \& Peters, J. M. Respiratory effects of relocating to areas of differing air pollution levels. Am. J. Respir. Crit. Care Med., 164(11):2067-72, 2001.

Balk, E. M.; Lichtenstein, A. H.; Chung, M.; Kupelnick, B.; Chew, P. \& Lau, J. Effects of omega-3 fatty acids on serum markers of cardiovascular disease risk: a systematic review. Atherosclerosis, 189(1):19-30, 2006.

Batstra, L.; Hadders-Algra, M. \& Neeleman, J. Effect of antenatal exposure to maternal smoking on behavioural problems and academic achievement in childhood: prospective evidence from a Dutch birth cohort. Early Hum. Dev., 75(1-2):21-33, 2003.

Berraies, A.; Hamzaoui, K. \& Hamzaoui, A. Link between vitamin D and airway remodeling. J. Asthma Allergy, 7:23-30, 2014.

Camargo, C. A. Jr.; Rifas-Shiman, S. L.; Litonjua, A. A.; Rich-Edwards, J. W.; Weiss, S. T.; Gold, D. R.; Kleinman, K. \& Gillman, M. W. Maternal intake of vitamin D during pregnancy and risk of recurrent wheeze in children at 3 y of age. Am. J. Clin. Nutr., 85(3):788-95, 2007.
Foong, R. E.; Shaw, N. C.; Berry, L. J.; Hart, P. H.; Gorman, S. \& Zosky, G. R. Vitamin D deficiency causes airway hyperresponsiveness, increases airway smooth muscle mass, and reduces TGF-b expression in the lungs of female BALB/c mice. Physiol. Rep., 2(3):e00276, 2014.

Gürkan, F.; Kiral, A.; Dag li, E. \& Karakoç, F. The effect of passive smoking on the development of respiratory syncytial virus bronchiolitis. Eur. J. Epidemiol., 16(5):465-8, 2000

Hofhuis, W.; Merkus, P. J. \& de Jongste, J. C. Negative effects of passive smoking on the (unborn) child. Ned. Tijdschr. Geneeskd., 146(8):356-9, 2002.

Jaakkola, J. K. \& Gissler, M. Maternal smoking in pregnancy, fetal development, and childhood asthma. Am. J. Public Health, 94(1):136-40, 2004.

Karlıkaya, C.; Öztuna, F.; Aytemur Solak, Z.; Özkan, M. \& Örsel, O. Tabaco control. Tütün Kontrolü. Toraks Derg., 7(1):51-64, 2006.

Lambert, D. S. \& Clark, K. E. The maternal and fetal physiologic effects of nicotine. Semin. Perinatol., 20(2):115-26, 1996.

Litonjua, A. A. Vitamin D deficiency as a risk factor for childhood allergic disease and asthma. Curr. Opin. Allergy Clin. Immunol., 12(2):179-85, 2012.

Mckeever, T. M.; Lewis, S. A.; Cassano, P. A.; Ocké, M.; Burney, P.; Britton, J. $\&$ Smit, H. A. The relation between dietary intake of individual fatty acids, FEV1 and respiratory disease in Dutch adults. Thorax, 63(3):208-14, 2008.

Oosthuizen, W.; Vorster, H. H.; Jerling, J. C.; Barnard, H. C.; Smuts, C. M.; Silvis, N.; Kruger, A. \& Venter, C. S. Both fish oil and olive oil lowered plasma fibrinogen in women with high baseline fibrinogen levels. Thromb. Haemost., 72(4):557-62, 1994.

Pattinson, H. A.; Taylor, P. J. \& Pattinson, M. H. The effect of cigarette smoking on ovarian function and early pregnancy outcome of in vitro fertilization treatment. Fertil. Steril., 55(4):780-3, 1991.

Romieu, I. \& Trenga, C. Diet and obstructive lung diseases. Epidemiol. Rev., 23(2):268-87, 2001.

Sahin, O.; Sulak, O.; Yavuz, Y.; Uz, E.; Eren, I.; Ramazan Yilmaz, H.; Malas, M. A.; Altuntas, I. \& Songur, A. Lithium-induced lung toxicity in rats: the effect of caffeic acid phenethyl ester (CAPE). Pathology, 38(1):58-62, 2006.

Schulte-Hobein, B.; Schwartz-Bickenbach, D.; Abt, S.; Plum, C. \& Nau, H. Cigarette smoke exposure and development of infants throughout the first year of life: influence of passive smoking and nursing on cotinine levels in breast milk and infant's urine. Acta Paediatr., 81(6-7):550-7, 1992.

Shimasaki, H. Assay of fluorescent lipid peroxidation products. Methods Enzymol., 233:338-46, 1994

Slinde, F.; Grönberg, A.; Engström, C. P.; Rossander-Hulthén, L. \& Larsson, S. Body composition by bioelectrical impedance predicts mortality in chronic obstructive pulmonary disease patients. Respir. Med., 99(8):1004-9, 2005.

Urrutia, R. P. \& Thorp, J. M. Vitamin D in pregnancy: current concepts. Curr. Opin. Obstet. Gynecol., 24(2):57-64, 2012.

Wasowicz, W.; Nève, J. \& Peretz, A. Optimized steps in fluorometric determination of thiobarbituric acid-reactive substances in serum: importance of extraction $\mathrm{pH}$ and influence of sample preservation and storage. Clin. Chem., 39(12):2522-6, 1993.

Wollmann, H. A. Intrauterine growth restriction: definition and etiology. Horm. Res., 49 Suppl. 2:1-6, 1998.

Young, G. \& Conquer, J. Omega-3 fatty acids and neuropsychiatric disorders. Reprod. Nutr. Dev., 45(1):1-28, 2002.

Zavos, P. M. Cigarette smoking: male and female infertility. Fertil. Contracept. Sex., 17(2):133-8, 1989.

Corresponding author:

Hakan Timur, M.D.

Bucak Mh. Ordu Üniversitesi Egitim Arastirma Hastanesi

Altinordu, 52200

Ordu

TURKEY

Email: drhakantimur@gmail.com

Received: 30-06-2018

Accepted: 30-08-2018 